\title{
Paclobutrazol in the flowering management affects the quality of Malpighia emarginata fruits $^{1}$
}

\author{
Erivan dos Santos Sousa ${ }^{2}$, Jackson Teixeira Lobo ${ }^{3}$, Daniel de Almeida Carreiro ${ }^{4}$, \\ Dayanne do Nascimento Dias ${ }^{4}$, Luciana Guimarães Sanches ${ }^{4}$, Ítalo Herbert Lucena Cavalcante ${ }^{4}$
}

\section{ABSTRACT}

Floral management using the growth regulator paclobutrazol may be an alternative for promoting the uniformity of flowering and fruiting in West Indian cherry (Malpighia emarginata D.C.) plants. However, the effects of its use on fruit quality are still unknown. This study aimed to evaluate the effect of paclobutrazol doses on the fruit quality of M. emarginata. The experimental design was randomized blocks, in a $2 \times 5$ factorial arrangement, with three replications and three plants per plot, with the studied factors consisting of two M. emarginata cultivars ('Junko' and 'Flor Branca') and five paclobutrazol doses $\left(0,0.4,0.8,1.2\right.$ and $1.6 \mathrm{~g}$ a.i. $\mathrm{m}^{-1}$ of canopy diameter). The following variables were evaluated: fruit mass, fruit transverse and longitudinal diameters, $\mathrm{pH}$, soluble solids content, titratable acidity, soluble solids/titratable acidity ratio and vitamin $\mathrm{C}$ content. The use of paclobutrazol, to some extent, promoted the increase of fruit mass, longitudinal diameter and soluble solids contents. The 'Junko' cultivar presented a higher vitamin C content than that for 'Flor Branca', and the maximum vitamin $\mathrm{C}$ contents were obtained with the paclobutrazol doses of 0.64 and $0.81 \mathrm{~g}$ a.i. $\mathrm{m}^{-1}$, respectively for the 'Junko' and 'Flor Branca' cultivars. None of the studied factors promoted differences for $\mathrm{pH}$ and fruit acidity.

KEYWORDS: West Indian cherry, floral induction, growth regulator.

\section{INTRODUCTION}

West Indian cherry (Malpighia emarginata D.C.) is a fruit species of the Malpighiaceae family, whose origin is undefined, although it has been reported to be native to the Caribbean and Antilles islands and commonly found in South America,

\section{RESUMO}

Paclobutrazol no manejo da floração afeta a qualidade de frutos de Malpighia emarginata

O manejo floral com a utilização do regulador de crescimento paclobutrazol pode ser uma alternativa para promover a uniformização do florescimento e frutificação em aceroleiras (Malpighia emarginata D.C.). No entanto, os efeitos de seu uso na qualidade dos frutos ainda são desconhecidos. Objetivou-se avaliar os efeitos de doses de paclobutrazol na qualidade de frutos de M. emarginata. $\mathrm{O}$ delineamento experimental foi em blocos casualizados, em arranjo fatorial 2 x 5, com três repetições e três plantas por parcela, com os fatores estudados consistindo de duas cultivares de aceroleira ('Junko' e 'Flor Branca') e cinco doses de paclobutrazol $(0 ; 0,4 ; 0,8 ; 1,2$; e $1,6 \mathrm{~g}$ i. a. $\mathrm{m}^{-1}$ de diâmetro de copa). As seguintes variáveis foram analisadas: massa dos frutos, diâmetro transversal e longitudinal dos frutos, $\mathrm{pH}$, teor de sólidos solúveis, acidez titulável, relação sólidos solúveis/acidez titulável e teor de vitamina C. O uso de paclobutrazol, até certa medida, promoveu o aumento da massa, diâmetro longitudinal e teores de sólidos solúveis dos frutos. A cultivar 'Junko' apresentou teor de vitamina C superior ao da 'Flor Branca', e os máximos teores de vitamina $\mathrm{C}$ foram obtidos com as doses de paclobutrazol de 0,64 e $0,81 \mathrm{~g}$ i.a. $\mathrm{m}^{-1}$, respectivamente para as cultivares 'Junko' e 'Flor Branca'. Nenhum dos fatores estudados promoveu diferenças para $\mathrm{pH}$ e acidez dos frutos.

PALAVRAS-CHAVE: Acerola, indução floral, regulador de crescimento.

Central America and southern Mexico (Moura et al. 2018). In Brazil, it is present mainly in the Northeast region, where edaphoclimatic conditions are favorable to its development (Batista et al. 2018).

$M$. emarginata is widely used in the food and pharmaceutical industries as a natural source of vitamin C, with contents that may exceed 50-100 times

${ }^{1}$ Received: Apr. 02, 2020. Accepted: July 08, 2020. Published: July 31, 2020. DOI: 10.1590/1983-40632020v5062805.

${ }^{2}$ Universidade Federal do Piauí, Centro de Ciências Agrárias, Bom Jesus, PI, Brasil.

E-mail/ORCID: erivansantosagro@hotmail.com/0000-0003-2740-0015.

${ }^{3}$ Universidade Federal da Paraíba, Centro de Ciências Agrárias, Areia, PB, Brasil. E-mail/ORCID: jackson_lob@hotmail.com/0000-0002-6978-083X.

${ }^{4}$ Universidade Federal do Vale do São Francisco, Campus de Ciências Agrárias, Petrolina, PE, Brasil.

E-mail/ORCID: daniel.almeida.sb@gmail.com/0000-0003-1048-7038, dayanne-dias@outlook.com/0000-0001-6506-7685, luciana-saanches@hotmail.com/0000-0003-2319-009X, italo.cavalcante@univasf.edu.br/0000-0003-1610-1546. 
those present in orange and lemon (Almeida et al. 2014), besides being rich in nutrients such as carotenoids, phenolic compounds, flavonoids and anthocyanins (Batista et al. 2018). Despite all the advantages associated with the nutraceutical properties of the fruit, its agronomic exploration faces some difficulties, mainly related to flowering and fruiting management. This plant presents an uneven and continuous flowering after outbreaks of vegetative growth, which provides a simultaneous presence of flowers and fruits in various stages of development, a factor that increases harvest and production costs (Almeida et al. 2014).

In this perspective, plant growth regulators, such as paclobutrazol (PBZ), have been studied as an alternative for the promotion of uniformity in flowering and production (Michelini \& Chinnery 1988, Michelini \& Chinnery 1989). However, the effects on the quality of $M$. emarginata fruits are still unknown.

Paclobutrazol [(2RS, 3RS)-1-(4-clorofenil)4,4-dimethyl-2-(1H-1,2,4-triazole-1-il) pentan-3-ol] belongs to the triazoles group and acts by inhibiting the oxidation of ent-kaurene into ent-kaurenoic acid, in the second phase of gibberellin biosynthesis (Rademacher 2016), promoting the reduction of cell elongation and division in plants and, consequently, affecting growth, besides improving flowering uniformity.

Physiological changes in plants induced by the action of PBZ may cause modifications in the physicochemical quality of fruits (Barman \& Mishra 2018). In avocado (Persea americana), Brogio et al. (2018) reported an increase of fruit mass and size; while, in 'Palmer' mango (Mangifera indica L.), Oliveira et al. (2015) observed a reduction in the soluble solids content. Oliveira et al. (2017), however, reported no effect of PBZ on the physical and chemical characteristics of 'Ubá' mango.

Therefore, the present study was developed to evaluate the fruit quality of the $M$. emarginata 'Junko' and 'Flor Branca' cultivars, as a function of PBZ doses on flowering management.

\section{MATERIAL AND METHODS}

The experiment was conducted at an experimental orchard of the Universidade Federal do Vale do São Francisco (09 $21^{\circ}$ 'S, 40 $34^{\circ}$ 'W and $365 \mathrm{~m}$ above the sea level), in Petrolina, Pernambuco state, Brazil, from January to May 2016. The climate of this region is classified as Bsh, semiarid, with mean annual rainfall of less than $500 \mathrm{~mm}$ (Alvares et al. 2013).

The Malpighia emarginata D.C. 'Junko' and 'Flor Branca' cultivars, propagated by grafting (with 'Junko' as rootstock) and with uniform vigor and canopy size, were used in this study.

The physical and chemical characteristics of the soil at the $0-20 \mathrm{~cm}$ and $20-40 \mathrm{~cm}$ depths were determined before the installation of the experiment (Table 1). The soil was classified as a typical cohesive Yellow Argisol (Silva et al. 2017).

The plants were spaced by $2.5 \mathrm{~m}$ between plants and $4.0 \mathrm{~m}$ between rows, and were daily irrigated using a micro-sprinkler system, with water supply equivalent to the daily evapotranspiration. Fertilization was performed weekly via fertigation, based on the results of the soil analysis (Table 1): $200 \mathrm{~g}$ of $\mathrm{N}$ and $150 \mathrm{~g}$ of $\mathrm{K}_{2} \mathrm{O}$ per plant were provided throughout the production cycle, in addition to foliar fertilizers with soluble compounds $(10 \%$ of N, $8 \%$ of $\mathrm{P}_{2} \mathrm{O}_{5}, 8 \%$ of $\mathrm{K}_{2} \mathrm{O}, 0.5 \%$ of $\mathrm{Mg}, 1 \%$ of Ca, $2 \%$ of S, $1 \%$ of $\mathrm{Zn}, 0.5 \%$ of B, $0.1 \%$ of Fe, $0.1 \%$ of Mo, $0.2 \%$ of $\mathrm{Cu}$ and $0.5 \%$ of $\mathrm{Mn}$ ) at the dose of $1 \mathrm{~mL} \mathrm{~L}^{-1}$.

The adopted experimental design was randomized blocks, in a $2 \times 5$ factorial arrangement, with three replications and three plants per plot. The treatments consisted of two M. emarginata cultivars ('Junko' and 'Flor Branca') under floral management and five paclobutrazol doses $(0,0.4,0.8,1.2$ and $1.6 \mathrm{~g}$ a.i. $\mathrm{m}^{-1}$ of canopy diameter).

Table 1. Chemical and physical characteristics of the soil at the depths of $0-20 \mathrm{~cm}$ and $20-40 \mathrm{~cm}$, before the experiment installation.

\begin{tabular}{lrc}
\hline \multirow{2}{*}{ Soil characteristics } & \multicolumn{2}{c}{ Value } \\
\cline { 2 - 3 } & $0-20 \mathrm{~cm}$ & $20-40 \mathrm{~cm}$ \\
\hline $\mathrm{pH}\left(\mathrm{H}_{2} \mathrm{O}\right)$ & 6.20 & 5.40 \\
$\mathrm{Ca}^{2+}\left(\mathrm{cmol}_{\mathrm{c}} \mathrm{dm}^{-3}\right)$ & 2.10 & 2.00 \\
$\mathrm{Mg}^{2+}\left(\mathrm{cmol}_{\mathrm{c}} \mathrm{dm}^{-3}\right)$ & 1.40 & 1.20 \\
$\mathrm{Al}^{3+}\left(\mathrm{cmol}_{\mathrm{c}} \mathrm{dm}^{-3}\right)$ & 0.00 & 0.00 \\
$\mathrm{~K}^{+}\left(\mathrm{cmol}_{\mathrm{c}} \mathrm{dm}^{-3}\right)$ & 0.74 & 0.63 \\
$\mathrm{Na}^{+}\left(\mathrm{cmol}_{\mathrm{c}} \mathrm{dm}^{-3}\right)$ & 0.11 & 0.19 \\
$\mathrm{P}\left(\mathrm{mg} \mathrm{dm}^{-3}\right)$ & 207.00 & 58.00 \\
Organic matter $(\%)$ & 0.56 & 0.53 \\
Sand $\left(\mathrm{g} \mathrm{kg}^{-1}\right)$ & 95.00 & 11.00 \\
Silt $\left(\mathrm{g} \mathrm{kg}^{-1}\right)$ & 32.00 & 60.00 \\
Clay $\left(\mathrm{g} \mathrm{kg}^{-1}\right)$ & 870.00 & 774.00 \\
\hline
\end{tabular}

$\mathrm{P}, \mathrm{K}$ and $\mathrm{Na}$ : Melich 1; $\mathrm{Ca}, \mathrm{Mg}$ and $\mathrm{Al}: \mathrm{KCl} 1 \mathrm{M}$ extractor. 
Paclobutrazol was applied on January 27, 2016 (226 days after the seedling transplantation), in the morning, in four holes $(10 \mathrm{~cm}$ in diameter and $10 \mathrm{~cm}$ in depth) per plant, at a distance of $30 \mathrm{~cm}$ from the stem, following the recommendation of Mendonça et al. (2001) for the mango crop. PBZ doses were defined according to the results of Michelini \& Chinnery (1988), using as a source the commercial product Cultar ${ }^{\mathrm{TM}}$, whose doses were diluted in $1.0 \mathrm{~L}$ of water per plant. The reduction in the water supply began at 28 days after the paclobutrazol application and lasted for 15 days (Michelini \& Chinnery 1988).

The harvest began at 44 days and finished at 125 days after the PBZ application. During this period, two harvests were conducted per week, between 7:00 a.m. and 9:00 a.m. The evaluated fruits were in the stage of commercial maturity, characterized by an external red color and sufficient firmness to support handling. The physicochemical quality analyses were performed on 15 fruits per plant, totaling 45 fruits per plot, with the total of evaluated fruits obtained from the successive harvests throughout the experimental period.

Fruit mass (g) was measured with a digital scale ( $0.5 \mathrm{~g}$ precision); the transverse and longitudinal diameters $(\mathrm{mm})$ were determined with a digital caliper (Insize ${ }^{\mathrm{TM}}$ series 1108); the $\mathrm{pH}$ in a PHS$3 \mathrm{E}$ benchtop $\mathrm{pH}$ meter; the soluble solids contents ( ${ }^{\circ}$ Brix) in an Abbe benchtop refractometer; while the total titratable acidity (g $100 \mathrm{~g}^{-1}$ of citric acid), soluble solids/titratable acidity ratio (SS/TA) and vitamin $\mathrm{C}\left(\mathrm{mg} 100 \mathrm{~g}^{-1}\right)$ were determined according to the Instituto Adolfo Lutz (IAL 2008).

The data were subjected to analysis of variance (Anova) by the F-test $(\mathrm{p}<0.05)$ and, if significant, the $\mathrm{PBZ}$ doses were subjected to regression analysis. The statistical analyses were performed with the Assistat software (Silva \& Azevedo 2016).

\section{RESULTS AND DISCUSSION}

According to the results of the analysis of variance (Table 2), there was a significant effect of the cultivar factor on fruit mass, fruit transverse and longitudinal diameters, vitamin $\mathrm{C}$ and SS/TA ratio. The factor PBZ doses affected the fruit mass, fruit longitudinal diameter and soluble solids content, while the 'cultivar x PBZ doses' interaction was only significant for the vitamin $\mathrm{C}$. No effect of the factors or the 'cultivar x PBZ' interaction was observed on $\mathrm{pH}$ and titratable acidity.

When analyzing the fruit mass as a function of the cultivars, it was observed that 'Junko' presented a result $35.27 \%$ higher than that obtained for 'Flor Branca' (Table 2). In a survey conducted in the São Francisco Valley, the same region in which this study was conducted, Batista et al. (2015) reported that, for the 'Flor Branca' cultivar, the mean fruit mass was $4.09 \mathrm{~g}$, a value $27.87 \%$ lower than that obtained in the present study.

When evaluating the results of fruit mass, regarding the PBZ dose factor, an adjustment to the quadratic regression model was observed, with a positive effect on the estimated dose of $1.02 \mathrm{~g} \mathrm{~m}^{-1}$ of the canopy and a maximum value of $7.07 \mathrm{~g}$, with a decrease in this variable with higher PBZ doses (Figure 1).

Brogio et al. (2018), evaluating the effect of gibberellin inhibitors on 'Hass' avocado, observed that the PBZ dose of $1,750 \mathrm{mg} \mathrm{L}^{-1}$, via foliar spraying, provided an increase of $20.3 \mathrm{~g}$ in fruit mass, corroborating the results found by Barman \& Mishra (2018), who observed that the application of $3.2 \mathrm{~mL}$

Table 2. Analysis of variance for fruit mass (FM), fruit transverse diameter (TD), fruit longitudinal diameter (LD), pH, soluble solids content (SS), total titratable acidity (TA), soluble solids/titratable acidity ratio (SS/TA) and vitamin C content, as a function of cultivars and PBZ doses.

\begin{tabular}{|c|c|c|c|c|c|c|c|c|}
\hline Source of variation & $\begin{array}{c}\text { FM } \\
\text { g }\end{array}$ & TD & LD & $\mathrm{pH}$ & $\begin{array}{c}\text { SS } \\
{ }^{\circ} \text { Brix }\end{array}$ & $\begin{array}{c}\text { TA } \\
\text { g } 100 \mathrm{~g}^{-1}\end{array}$ & SS/TA & $\begin{array}{l}\text { Vitamin C } \\
\mathrm{mg} 100 \mathrm{~g}^{-1}\end{array}$ \\
\hline Cultivar (C) & $25.04 *$ & $33.45^{*}$ & $60.73^{*}$ & $0.34^{\mathrm{ns}}$ & $2.63^{\mathrm{ns}}$ & $3.03^{\mathrm{ns}}$ & $10.25 *$ & $30.91 *$ \\
\hline 'Junko' & $7.67 \mathrm{a}$ & $24.92 \mathrm{a}$ & $21.40 \mathrm{a}$ & 3.15 & 6.39 & 1.24 & $5.17 \mathrm{~b}$ & $1,842.03 \mathrm{a}$ \\
\hline 'Flor Branca' & $5.67 \mathrm{~b}$ & $21.61 \mathrm{~b}$ & $18.52 \mathrm{~b}$ & 3.17 & 6.92 & 1.11 & $6.41 \mathrm{a}$ & $1,372.81 \mathrm{~b}$ \\
\hline $\mathrm{PBZ}(\mathrm{P})$ & $1.24^{*}$ & $1.79^{\mathrm{ns}}$ & $1.25^{*}$ & $1.67^{\mathrm{ns}}$ & $0.42 *$ & $0.21^{\mathrm{ns}}$ & $0.55^{\mathrm{ns}}$ & $2.82^{\text {ns }}$ \\
\hline $\mathrm{C} \times \mathrm{P}$ & $0.85^{\text {ns }}$ & $1.21^{\mathrm{ns}}$ & $0.51^{\mathrm{ns}}$ & $1.46^{\mathrm{ns}}$ & $1.10^{\text {ns }}$ & $0.18^{\mathrm{ns}}$ & $0.35^{\text {ns }}$ & $0.35^{*}$ \\
\hline CV (\%) & 16.35 & 6.72 & 5.08 & 3.06 & 13.48 & 17.32 & 18.34 & 14.38 \\
\hline
\end{tabular}

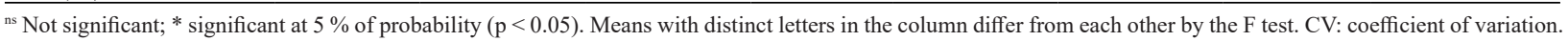




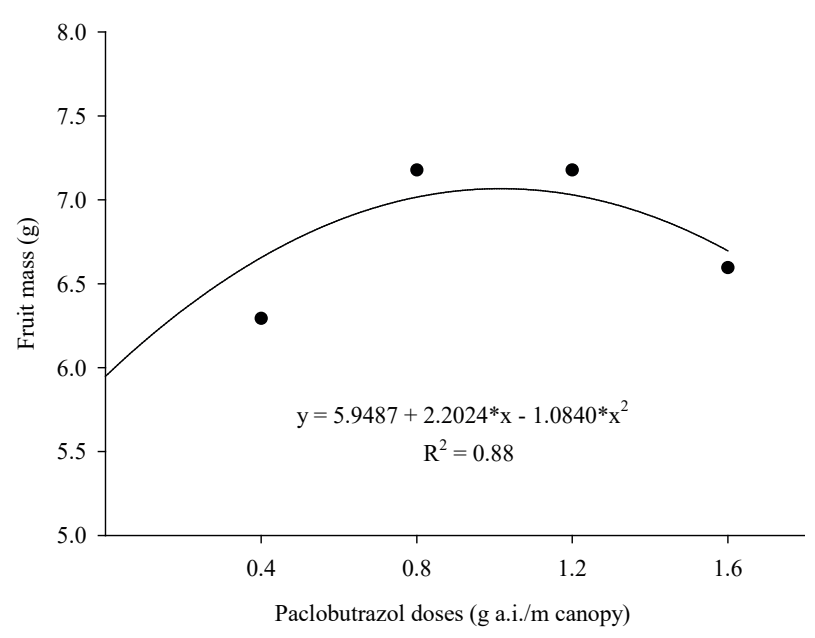

Figure 1. Mass of Malpighia emarginata fruits, as a function of paclobutrazol doses.

per linear meter of the canopy during floral induction, in 'Dashehari' mango, provided an increase in fruit weight, in relation to the control treatment.

Paclobutrazol is commonly used to reduce the vegetative growth in plants, thereby reducing the leaf area expansion and altering the source-drain balance, resulting in a greater allocation of photoassimilates to fruits (Reddy et al. 2013), what can favor their growth (Barman \& Mishra 2018) and, consequently, lead to a higher accumulation of fresh matter. However, it is known that the effects caused by the use of plant regulators vary according to factors such as edaphoclimatic conditions, plant species, cultivar and application form.

For the fruit transverse diameter, 'Junko' presented results superior to those of the 'Flor Branca' cultivar, with a difference of $3.31 \mathrm{~mm}$, although the PBZ application did not affect this variable (Table 2).

Regarding the longitudinal diameter, 'Junko' was also superior, with a result $2.92 \mathrm{~mm}$ higher than for 'Flor Branca' (Table 2). Menezes et al. (2018), evaluating nine different $M$. emarginata genotypes, observed measurements of transverse and longitudinal diameters ranging from $19.33 \mathrm{~mm}$ to $24.67 \mathrm{~mm}$ and from $17.51 \mathrm{~mm}$ to $21.25 \mathrm{~mm}$, respectively, ranges that include the results obtained for the two cultivars evaluated in this study.

M. emarginata fruits may exhibit a diameter between $10 \mathrm{~mm}$ and $40 \mathrm{~mm}$ (Prakash \& Baskaran 2018), and the differences observed in the present study are justified by the genetic characteristics of the cultivars, since 'Junko' tends to present larger fruits than 'Flor Branca' (Souza et al. 2014).

For the isolated effect of the PBZ doses, the longitudinal diameter results adjusted to the quadratic regression model (Figure 2), with an increment up to the dose of $0.99 \mathrm{~g}$ a.i. PBZ m${ }^{-1}$, estimating the best performance of $23.99 \mathrm{~mm}$, followed by a reduction when increasing the PBZ doses.

Cavatte et al. (2012) observed that, for the 'Prata-Anã' banana cultivar, the use of PBZ reduced the fruit diameter; while, for the 'FHIA-01' cultivar, the responses to the different doses presented a quadratic behavior, with the highest recorded value of $0.92 \mathrm{~g} \mathrm{plant}^{-1}$, exhibiting deleterious effects at higher doses. During the fruit growth process, cell division plays an essential initial role, with the later predominance of cell expansion for the increase of fruit volume (Chitarra \& Chitarra 2005).

For the soluble solids content (Figure 3), the results adjusted to the quadratic regression model, as a function of the PBZ doses, with a maximum value of $6.85^{\circ} \mathrm{Brix}$ at the dose of $0.38 \mathrm{~g}$ a.i. $\mathrm{PBZ} \mathrm{m}^{-1}$, decreasing from this point and reaching the lowest

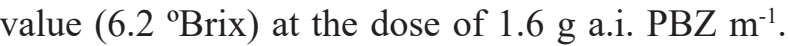
However, the values obtained are above the minimum quality of $5.5^{\circ}$ Brix established by the Brazilian Ministry of Agriculture, Livestock and Supply (Brasil 2018).

Apparently, the effect of PBZ on soluble solids contents varies according to the crop and cultivar used. Oliveira et al. (2015) observed an increase in this variable, as a function of the use of PBZ

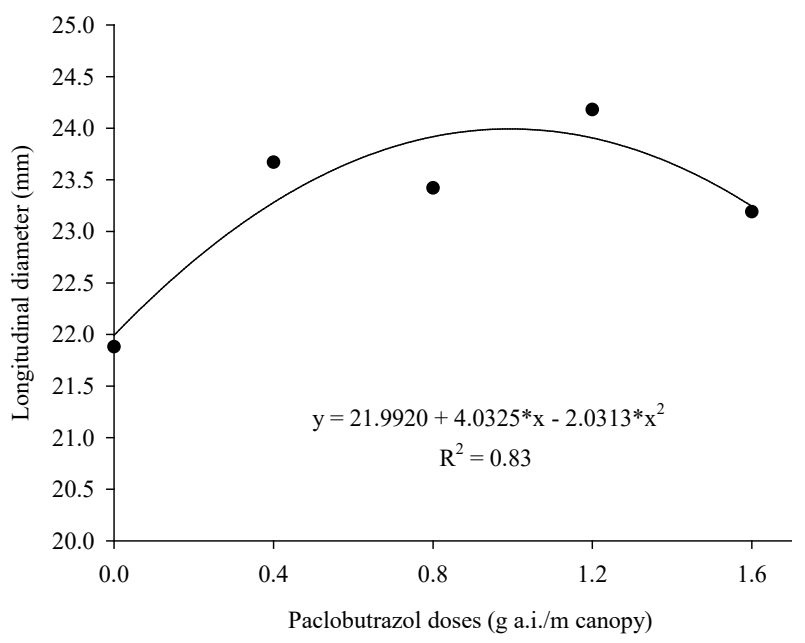

Figure 2. Longitudinal diameter of Malpighia emarginata fruits, as a function of paclobutrazol doses. 


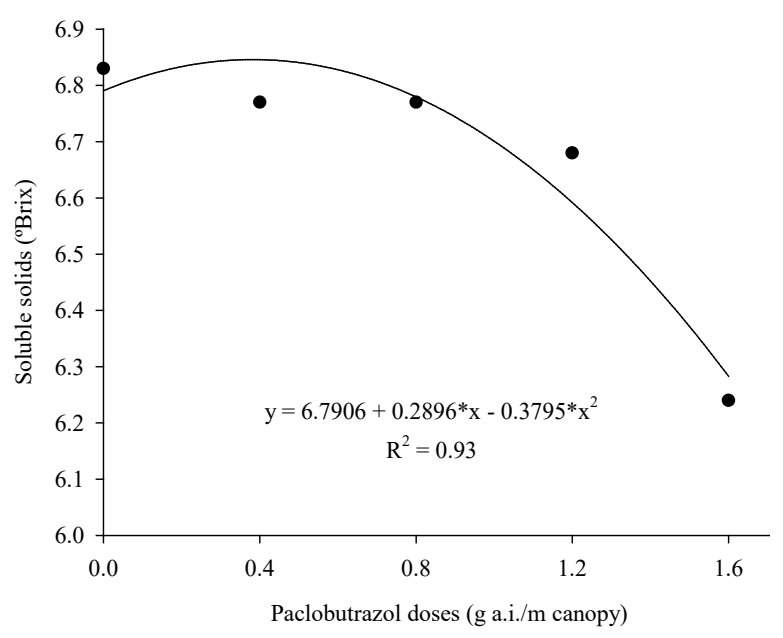

Figure 3. Soluble solids content of Malpighia emarginata fruits, as a function of paclobutrazol doses.

in 'Palmer' mango, verifying a faster degradation in the postharvest period. However, Steffens et al. (1983) reported that PBZ may negatively affect alpha-amylase gene expressions, whose function is to catalyze the conversion of starch into sugars, justifying the linear decreasing behavior observed for soluble solids.

For the SS/TA ratio (Table 2), there was an increase of 1.24 for 'Flor Branca', when compared to 'Junko', justified by the higher soluble solids content and lower titratable acidity of 'Flor Branca', despite the non-significant difference for soluble solids and titratable acidity when evaluated separately. Menezes et al. (2018), studying the physical and chemical characterization of $M$. emarginata genotypes, observed values from 3.48 to 7.22 , a range that includes the results in the present study. In contrast, Corrêa et al. (2017) obtained a 10.73 ratio in fruits of $M$. emarginata cv. 'Olivier', with the difference justified by the lower titratable acidity observed by the authors.

When analyzing the unfolding of the interaction for the vitamin C content (Figure 4), it is observed that, for all evaluated doses, 'Junko' provided better results than 'Flor Branca', with recorded differences of 634.21, 474.31, 405.91, 497.27 and

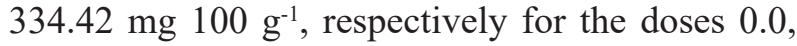
$0.4,0.8,1.2$ and $1.6 \mathrm{~g}$ a.i. $\mathrm{PBZ} \mathrm{m}^{-1}$.

The vitamin $C$ levels were affected by the PBZ doses, presenting a quadratic response in both cultivars (Figure 4). For 'Junko', the maximum estimated level was $1,985.34 \mathrm{mg} 100 \mathrm{~g}^{-1}$ of pulp at

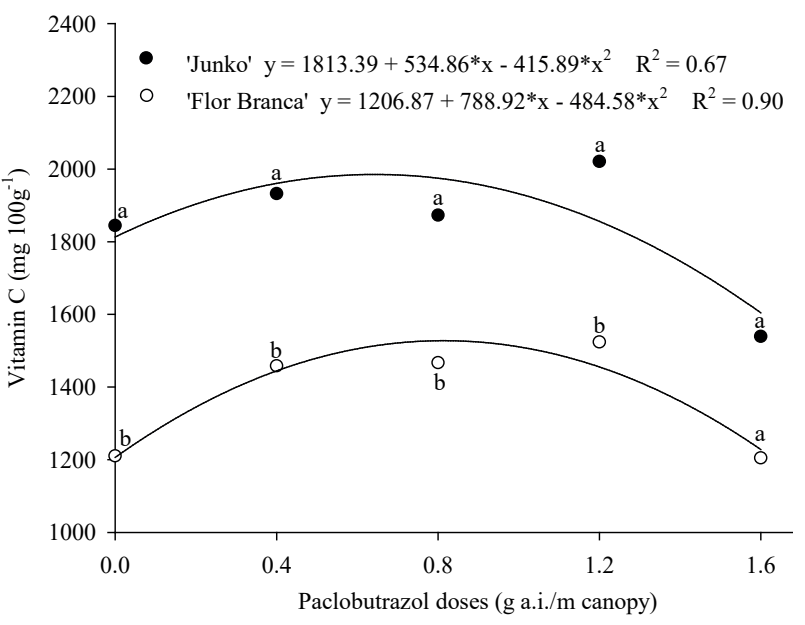

Figure 4. Vitamin C content of Malpighia emarginata fruits, as a function of cultivars and paclobutrazol doses.

the dose of $0.64 \mathrm{~g}$ a.i. PBZ m${ }^{-1}$; whereas, for 'Flor

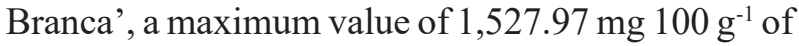
pulp was observed at the dose of $0.81 \mathrm{~g}$ a.i. $\mathrm{PBZ} \mathrm{m}^{-1}$. It is then noted that 'Junko' requires a $0.17 \mathrm{~g}$ a.i. $\mathrm{PBZ} \mathrm{m}^{-1}$ lower dose to obtain a pulp content greater than

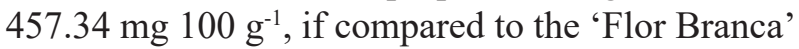
cultivar.

The vitamin $\mathrm{C}$ content of the 'Flor Branca' cultivar was also evaluated by Batista et al. (2018), who

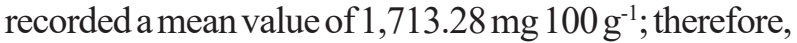
$341.18 \mathrm{mg} 100 \mathrm{~g}^{-1}$ higher than registered in this study for the same cultivar, but lower than the results obtained for the 'Junko' cultivar, which also presented a higher result than the values of 1,074.75 and

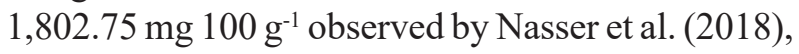
except for the result of $1.6 \mathrm{~g}$ a.i. $\mathrm{PBZ} \mathrm{\textrm {m } ^ { - 1 }}$.

The effect of PBZ on the vitamin $\mathrm{C}$ content of fruit species present divergences in the scientific literature. Rehman et al. (2018), evaluating the effect of the pre-harvest application of prohexadionecalcium and PBZ on the fruit quality of 'M7' oranges (Citrus sinensis L. Osbeck), observed no significant effect on the vitamin $C$ content, whereas a depressive effect on this variable was identified in fruits of the 'Red Delicious' apple cultivar (Malus domestica L.), in plants treated with PBZ via soil (Wani et al. 2007).

Apparently, gibberellin affects the anthocyanin content in the fruit, depending on the applied amount (Souza et al. 2017). Rosso \& Mercadante (2007) affirm that anthocyanins may condense with vitamin $\mathrm{C}$ and promote an accelerated degradation of these compounds. In this sense, it is believed that PBZ 
may have affected the total anthocyanin content of the fruit by promoting low endogenous gibberellin levels, fostering positive effects on the vitamin $\mathrm{C}$ content up to a certain dose.

For $\mathrm{pH}$, the mean value observed for M. emarginata was 3.16, regardless of the cultivar; while, for titratable acidity, the mean value was

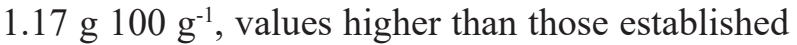
for the pulp quality standards of $M$. emarginata,

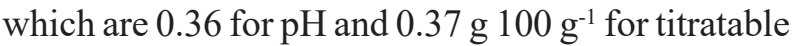
acidity (Brasil 2018).

\section{CONCLUSIONS}

1. The 'Junko' cultivar presents higher physical quality and vitamin $\mathrm{C}$ contents than 'Flor Branca', although 'Flor Branca' has a higher soluble solids/ titratable acidity ratio;

2. The application of paclobutrazol in floral management affects the quality of Malpighia emarginata fruits. The dose of approximately $1 \mathrm{~g}$ a.i. $\mathrm{m}^{-1}$ provides the highest fruit mass and longitudinal diameter; $0.38 \mathrm{~g}$ a.i. $\mathrm{m}^{-1}$ the highest soluble solids content; and the maximum vitamin $\mathrm{C}$ contents were obtained with doses of 0.64 and $0.81 \mathrm{~g}$ a.i. $\mathrm{m}^{-1}$, respectively for the 'Junko' and 'Flor Branca' cultivars.

\section{REFERENCES}

ALMEIDA, S. S.; ALVES, M. A. L.; ARAÚJO, S. A.; SANTANA, J. C. C.; NARAIN, N.; SOUZA, R. R. Use of simulated annealing in standardization and optimization of the acerola wine production. Food Science and Technology, v. 34, n. 2, p. 292-297, 2014.

ALVARES, C. A.; STAPE, J. L.; SENTELHAS, P. C.; GONÇALVES, J. L. M.; SPAROVEK, G. Köppen's climate classification map for Brazil. Meteorologische Zeitschrift, v. 22, n. 6, p. 711-728, 2013.

BARMAN, P.; MISHRA, D. Tip pruning for synchronized vegetative growth and controlling alternate bearing in mango (Mangifera indica). Indian Journal of Agricultural Sciences, v. 88, n. 4, p. 621-627, 2018.

BATISTA, P. F.; LIMA, M. A. C.; ALVES, R. E.; FAÇANHA, R. V. Bioactive compounds and antioxidant activity in tropical fruits grown in the lower-middle São Francisco Valley. Revista Ciência Agronômica, v. 49, n. 4, p. 616-623, 2018.

BATISTA, P. F.; LIMA, M. A. C.; TRINDADE, D. C. G.; ALVES, R. E. Quality of different tropical fruit cultivars produced in the lower basin of the São Francisco Valley. Revista Ciência Agronômica, v. 46, n. 1, p. 176-184, 2015.

BRASIL. Ministério da Agricultura, Pecuária e Abastecimento. Regulamento técnico geral para fixação dos padrões de identidade e qualidade para suco de acerola. Brasília, DF: MAPA, 2018.

BROGIO, B. A.; SILVA, S. R.; CANTUARIAS-AVILÉS, T.; ANGOLINI, S. F.; BAPTISTA, E. G.; RIBEIRO, R. V. Influence of gibberellin inhibitors applied during flowering of nonirrigated 'Hass' avocado trees. Pesquisa Agropecuária Brasileira, v. 53, n. 8, p. 918-923, 2018.

CAVATTE, R. P. Q.; SALOMÃO, L. C. C.; SIQUEIRA, D. L.; PETERNELLI, L. A.; CAVATTE, P. C. Redução do porte e produção das bananeiras 'Prata-Anã' e 'FHIA01' tratadas com paclobutrazol. Revista Brasileira de Fruticultura, v. 34, n. 2, p. 356-365, 2012.

CHITARRA, M. I. F.; CHITARRA, A. B. Pós-colheita de frutas e hortaliças: fisiologia e manuseio. 2. ed. Lavras: Ed. UFLa, 2005.

CORREAA, C. V.; GOUVEIA, A. M. S.; MARTINS, B. N. M.; JORGE, L. G.; LANNA, N. B. L.; TAVARES, A. E. B.; MENDONÇA, V.Z.; EVANGELISTA, R. M. Influence of ripening stages on physicochemical characteristics of acerola fruits. Revista de Ciências Agrárias, v. 40, n. 4, p. 130-139, 2017.

INSTITUTO ADOLFO LUTZ (IAL). Métodos físicoquímicos para análise de alimentos. 4. ed. São Paulo: Instituto Adolfo Lutz, 2008.

MENDONÇA, V.; ARAÚJO NETO, S. E.; HAFLE, O. M.; MENEZES, J. B.; RAMOS, J. D. Florescimento e frutificação de mangueira com uso de paclobutrazol, ethephon e nitrato de cálcio. Revista Brasileira de Fruticultura, v. 23, n. 2, p. 265-269, 2001.

MENEZES, T. P.; RUFINI, J. C. M.; PIO, L. A. S.; MAGALHÃES, D. S.; CHAIN, C. P. Physical and chemical characterization of fruits and DNA content in genotypes of acerola tree. Brazilian Journal of Agriculture, v. 93 , n. 3, p. 336-346, 2018.

MICHELINI, S.; CHINNERY, L. E. Enhanced multiple cropping in paclobutrazol-treated acerola. Acta Horticulturae, v. 239, n. 42, p. 281-284, 1989.

MICHELINI, S.; CHINNERY, L. E. The use of plant regulators and irrigation to control flowering of the acerola or Barbados cherry, Malpighia glabra L. Proceedings of the Interamerican Society for Tropical Horticulture, v. 32, n. 1, p. 65-73, 1988.

MOURA, C. F. H.; OLIVEIRA, L. S.; SOUZA, K. O.; FRANCA, L. G.; RIBEIRO, L. B.; SOUZA, P. A.; MIRANDA, M. R. A. Acerola - Malpighia emarginata. In: RODRIGUES, S.; SILVA, E. O.; BRITO, E. S. (ed.). 
Exotic fruits: reference guide. London: Elsevier, 2018. p. 7-14.

NASSER, M. D.; MARIANO-NASSER, F. A. de C.; FURLANETO, K. A.; RAMOS, J. A.; CAETANO, P. K. Composição da acerola de diferentes genótipos em duas épocas de colheita. Pesquisas Agrárias e Ambientais, v. 6, n. 1, p. 15-19, 2018.

OLIVEIRA, G. P.; SIQUEIRA, D. L.; SALOMÃO, L. C. C.; CECON, P. R.; MACHADO, D. L. M. Paclobutrazol and branch tip pruning on the flowering induction and quality of mango tree fruits. Pesquisa Agropecuária Tropical, v. 47, n. 1, p. 7-14, 2017.

OLIVEIRA, M. B.; PEREIRA, M. C. T.; MIZOBUTSI, G. P.; MAIA, V. M.; SILVA, J. F.; OLIVEIRA, J. A. A.; COSTA, I. J. S.; NIETSCHE, S.; SANTOS, E. F.; MOUCO, M. A. C. Paclobutrazol and tip pruning in the management of 'Palmer' mango trees in the semi-arid region of Brazil. Acta Horticulturae, v. 1075, n. 16, p. 149-156, 2015.

PRAKASH, A.; BASKARAN, R. Acerola, an untapped functional superfruit: a review on latest frontiers. Journal of Food Science and Technology, v. 55, n. 9, p. 3373-3384, 2018.

RADEMACHER, W. Chemical regulators of gibberellin status and their application in plant production. In: HEDDEN, P.; THOMAS, S. G. (ed.). The gibberellins. Chichester: John Wiley \& Sons, 2016. p. 359-404.

REDDY, Y. T. N.; SHIVU PRASAD, S. R.; UPRETI, K. K. Effect of paclobutrazol on fruit quality attributes in mango (Mangifera indica L.) cv. Totapuri. Journal of Horticultural Sciences, v. 8, n. 2, p. 236-239, 2013.

REHMAN, M.; SINGH, Z.; KHURSHID, T. Preharvest spray application of prohexadione-calcium and paclobutrazol improves rind colour and regulates fruit quality in M7 navel oranges. Scientia Horticulturae, v. 234, n. 1, p. 87-94, 2018.

ROSSO, V. V.; MERCADANTE, A. Z. The high ascorbic acid content is the main cause of the low stability of anthocyanin extracts from acerola. Food Chemistry, v. 103, n. 3, p. 935-943, 2007.

SILVA, F. A. S.; AZEVEDO, C. A. V. The Assistat software version 7.7 and its use in the analysis of experimental data. African Journal of Agricultural Research, v. 11, n. 39, p. 3733-3740, 2016.

SILVA, K. A.; RODRIGUES, M. S.; CUNHA, J. C.; ALVES, D. C.; FREITAS, H. R.; LIMA, A. M. N. Levantamento de solos utilizando geoestatística em uma área de experimentação agrícola em Petrolina - PE. Comunicata Scientiae, v. 8, n. 1, p. 175-180, 2017.

SOUZA, K. O.; MOURA, C. F. H.; BRITO, E. S.; MIRANDA, M. R. A. Antioxidant compounds and total antioxidant activity in fruits of acerola from cv. Flor Branca, Florida Sweet and BRS 366. Revista Brasileira de Fruticultura, v. 36, n. 2, p. 294-304, 2014.

SOUZA, K. O.; MOURA, C. F. H.; LOPES, M. M. A.; RABELO, M. C.; MIRANDA, M. R. A. Quality of acerola (Malpighia emarginata) treated with gibberelic acid and stored under refrigeration. Revista Brasileira de Fruticultura, v. 39, n. 4, e-574, 2017.

STEFFENS, G. L.; WANG, S. Y.; STEFFENS, C. L.; BRENNAN, T. Influence of paclobutrazol (PP 333) on apple seedling growth and physiology. Proceedings of the Plant Growth Regulator Society of America, v. 10, n. 1, p. 195-205, 1983.

WANI, A. M.; PEER, F. A.; LONE, I. A. Effect of paclobutrazol on growth, picking maturity and storage behaviour of Red Delicious apples. Asian Journal of Horticulture, v. 2, n. 1, p. 171-175, 2007. 